\title{
7. I told you so
}

Anyone who says 'I told you so' too often is liable to make himself unpopular. But, as the Lawson boom disintegrated in 1988 and 1989, my forecasts of rising inflation were vindicated. I felt justified in pointing out that I had warned the Government, well in advance of the event, that its economic policies would end badly.

In 1988 and 1989 the 'leading forecasting groups' (i.e., the London Business School and the National Institute of Economic Research), the Treasury and Government ministers had forgotten about monetarism, broad money targets and the like. Instead they had reverted to their practices in the early and mid-1970s, using forecasts from a large-scale macroeconomic model as the basis for short-term decisions about interest rates, tax changes and budgetary policy. They seem to have forgotten the catastrophe suffered by macroeconomic forecasting during and after the Barber boom, when all the models utterly failed to foresee either the severity of the fall in output in late 1974 and early 1975, or the scale of the concurrent increase in inflation. The late 1980s were a very similar period. Once again the mainstream economic forecasts were hopelessly wrong and policy decisions based upon them were often inappropriate.

Two of the four pieces in this section refer to macroeconomic forecasting. The first, 'Quick, quick, slow, stop-go', from The Times of 25 July 1988, was probably my sharpest attack on Lawson personally. He ought to have known, from many years of experience as a financial journalist and politician, that Treasury forecasts were not to be taken too literally. But he was clearly duped by the inept and totally wrong forecast produced by his Treasury officials before the 1988 Budget. The forecast was that the economy would slow down to a moderate rate of growth, with no significant rise in inflation and no large change in interest rates. Lawson, still relying on his Treasury forecasters, continued to promise this so-called 'soft landing' until his resignation in 1989.

The second article, 'Scribblers in the stocks', from The Times of 27 September 1988, turned its attention to the large number of 'publicity-seeking "teenage scribblers"' who began to jeer at Lawson and the Treasury's forecasting record in late 1988. My point was that virtually all of them had produced the same forecast as the Treasury in late 1987 and early 1988! 
Sadly, these economists had a 'propensity, when asked about the future, to transform themselves into computerized sheep'.

\section{Quick, Quick, Slow, Stop-Go}

Reprinted from the an article of the same name in The Times of 25 July 1988.

Note the reference to the change in monetary policy in mid-1985, followed by 'a clear change in the behaviour of all the relevant variables - bank lending, mortgage credit, M3, M4 and M5 - by early 1986', as the start of Lawson's troubles. By late 1988 most politically-aware economists realized that Lawson had mishandled the economy, but many attributed higher inflation to the 1988 Budget. In my view, the causes of rising inflation had to be sought much earlier.

At long last the Government has accepted what most economic scribblers, from the teenage to the geriatric, have known for many months. The British economy has enjoyed a full-scale boom since mid-1986, with domestic demand rising more strongly than at any time since the Heath-Barber 'dash for growth' of the early 1970s. The Treasury has spent most of the last two years wrongly forecasting an imminent and spontaneous slowdown in economic activity. By endorsing the Bank of England's recent moves to raise clearing bank base rates by 3 per cent in a mere six weeks, it has finally approved action which makes a slowdown conceivable.

But there is still a debate about how smoothly the economy will return to a moderate pace of expansion. Mr Lawson, and presumably most of his Cabinet colleagues and Treasury advisers, believe there will be a gentle touchdown to the sustainable medium-term growth rate of about $2^{1 / 2}$ to 3 per cent. In their view, this touchdown can be achieved without an intervening recession or even a short period of beneath-trend growth, while the inflation rate will remain at about 5 per cent and the balance of payments, although in deficit, will not be a problem.

The alternative view is that the economy will suffer a hard landing. In this argument, the pressure of excess demand is bound to cause persisting balanceof-payments weakness and a sharp rise in inflation. Once the severity of the inflation difficulties is recognized, the Government will be obliged to engineer a further deceleration in the speed of economic expansion. A year or two of slow growth, involving some rise in unemployment, will be needed to eliminate the labour and capacity shortages which are the immediate causes of more inflation. It will seem retrospectively that the Lawson boom, like its 
many predecessors in the post-war period, was part of just another stop-go cycle.

The strategic disagreement between the optimists and pessimists will not be settled conclusively until the end of 1989 , if not later. But the optimists at the Treasury have already suffered heavy tactical defeats from the economic data of the last few months. The official Budget-time forecasts of a $£ 4$ billion current account deficit and year-end 4 per cent inflation have already had to be revised upwards. The Treasury has rather shamefacedly declined to give a precise figure for its new payments forecast, but a $£ 10$ billion deficit is quite possible. (More will be known with the publication of the June trade figures on Wednesday.) Meanwhile several private forecasters envisage a $5^{1 / 2}$ to 6 per cent increase in retail prices this year.

Indeed, the scale of the mistake with the payments forecast has been such as to raise doubts about the basis for the Chancellor's continuing complacency. It needs to be emphasized that this is not the first time in recent years that the official forecast has gone astray. At Budget time last year the Treasury expected gross domestic product to rise by 3 per cent in 1987. In fact growth was about $4 \frac{1}{2}$ per cent.

The forecasting errors made in the Budgets of both 1987 and 1988 point to two conclusions. The Treasury completely failed to appreciate the vigour of the upturn in economic activity which began in mid-1986; and most members of the Government, including the Prime Minister, had no advance warning that there was going to be a boom on the scale actually experienced. In the circumstances it is not surprising that Mrs Thatcher is more worried about overheating and inflation than her Chancellor, or that she is seeking new sources of advice.

Why have Lawson and the Treasury been so badly wrong? By far the most convincing general explanation is that the Chancellor stopped paying much attention to credit and broad money about three years ago and attached no importance to the accelerating growth of both which began in late 1985 . This acceleration was foreshadowed in both the 1985 Budget and the Mansion House speech of October 1985, and can reasonably be described as the inevitable consequence of the change in policy approach. There was a clear change in the behaviour of all the relevant variables - bank lending, mortgage credit, M3, M4 and M5 - by early 1986.

It is not possible in a short article to review all the evidence. Instead we will focus on just one statistic, the increase in M3 adjusted for inflation, which may be called the 'real money supply'. It is perhaps the best indicator of the influence being exerted on economic activity by changes in personal and corporate liquidity. In periods of monetary relaxation it measures the stimulatory push coming from excess money growth. In the five years to the beginning of 1986 the real money supply increased on average by 5 per cent 
a year, with only small annual variations. This growth rate was associated with impressive economic stability and was only slightly higher than the $21 / 2$ to 3 per cent growth of output. The whole period was the heyday, indeed almost the golden age, of the Medium-Term Financial Strategy, with ministers, from Mrs Thatcher downwards, trumpeting the success of their anti-inflationary policies.

By contrast, since the beginning of 1986 the real money supply has increased by an average annual rate of 17 per cent. This upturn was particularly marked in early 1986, mainly because the oil price fall led to an exceptional fall in inflation, but it has continued until the present. The economy has been asked to absorb an injection of liquidity out of all proportion to the sustainable rise in output. This total change in the monetary environment is the main cause - indeed, practically the only cause - of the Lawson boom. It is by far the most important reason that house prices are rising by more than 20 per cent a year; that fewer companies consider themselves to have excess capacity than at any time in the last 30 years; that pay settlements are edging up after the largest two-year fall in unemployment in our history; and that of the balance-of-payments current account has worsened by the equivalent of more than $1 / 2$ per cent of GDP in each of the last six quarters.

If the essentials of this argument are accepted, a precondition for a return to sustainable $2^{1 / 2}$ to 3 per cent growth is that monetary expansion falls back to the rate seen in the five years to 1986 . That rate is at most about 5 per cent a year in inflation-adjusted terms and about 10 to 12 per cent a year in terms of actual numbers. The latest monthly figures are disturbing since they suggest that this goal is remote. Bank lending in June was at an all-time record of $£ 6.1$ billion, the boom in mortgage credit continues and M3 growth over the last year is still at 20 per cent. Since there is some short-term inertia in credit trends, it will take several months and a few additional interest rate rises before the pace of economic expansion does moderate significantly. The Government will be lucky if, after virtually three years of monetary excess, the inflation rate can be easily held near to the 5 per cent figure. A hard landing, with an awkward phase of economic adjustment, coming at an inconvenient stage in the electoral cycle, is more probable than a smooth touchdown.

Lawson's personal attitude towards the events of the last three years is a puzzle. In the early 1980s he was the most vocal 'monetarist' in the Government; in the mid-1980s he was its most deliberate pragmatist; but in a speech earlier this month he is said to have reiterated, apparently with a straight face, that 'inflation is pre-eminently a monetary phenomenon'.

It has been an extraordinary performance. A few months ago the right image for the Chancellor's intellectual evolution would have been a somer- 
sault, as he turned on its head the official orthodoxy of the Government's early years. But, if the latest shift in his statements is to be taken at face value, this would be greatly to underestimate his gymnastic abilities. A more appropriate image now is the pirouette, as he swirls round trying to find a credible theoretical justification for the latest twist in the erratic course of macroeconomic policy. In the last three years he has effectively destroyed all that he stood for, in terms of the structure of policy, in the previous five. It is an impressive tribute to his skills of presentation that he is still regarded by the media, and the majority of Conservative MPs, as the most successful Chancellor since the war and, by the Prime Minister, as 'quite brilliant' in his recent conduct of policy.

\section{On Teenage Scribblers and Computerized Sheep}

From an article 'Scribblers in the stocks' in The Times of 27 September 1988.

This article was another polemic, but I think it made some useful points. In particular, it asked why so many economists could be wrong so often in more or less the same way. The answer was, at least in part, that 'the computerized sheep' shared the same 'framework of thought and the model which incorporates it'. The argument is developed below on pp. 191-4 in an article on 'The importance of money in macroeconomic forecasting - part 2', based on an article in The Spectator of 11 March 1989, and it harks back to the article 'A lesson from the Treasury on how to be precisely wrong' in The Times of 28 August 1975.

It has become fashionable to sneer at Mr Lawson and the Treasury. Why, it is asked, did the Government fail to anticipate the excessive domestic demand and a widening payments deficit? Lawson, who was even more self-confident than usual about the economy earlier this year, has been censured for pushing his luck too far by cutting taxes in the middle of a consumer boom. Meanwhile the Treasury, whose Budget-time expectation of a slowdown in the economy was largely responsible for the Chancellor's complacency, has been criticized for bad forecasting.

Some of the most articulate critics have been City economists whose attacks have been given a sharper edge by Lawson's description of them two months ago as publicity-seeking 'teenage scribblers'. As the Government's own economic forecast for 1988 has proved increasingly inaccurate, the City scribblers have hit back by condemning official policy as irresponsible. The press has portrayed the argument between Lawson and the analysts as a high-grade Punch and Judy show: the analysts bash him with the July trade 
figures and the August money supply numbers. In reply, Lawson biffs the analysts, apparently on the grounds that they have not grown up.

The histrionics are great fun, but the press reporting is misleading in its assumption that the Chancellor has been wrong and the City scribblers right. The truth is that the City has been slightly more wrong than the Treasury in its appraisal of the economy this year. Although Lawson has every reason to be embarrassed about the forecasts he made in the Budget, the scribblers, instead of mocking the official errors, ought to be apologizing for theirs.

The facts are easy to check. In addition to preparing its own forecasts, the Treasury compiles a survey of independent forecasts, of which nine come from the City. An average of these nine can be regarded as the 'City consensus'. The forecast given by this consensus in March can readily be compared with the Treasury's own much derided figures. The Treasury view was that 1988 would see 3 per cent growth in gross domestic product, a 4 per cent rise in the retail price index in the year to the fourth quarter, and a current account deficit of $£ 4$ billion. In less than three months it had become clear that this forecast was grossly wrong. A more plausible assessment now is that growth will be 4 to $4^{1} / 2$ per cent, while inflation will reach 6 to $6^{1 / 2}$ per cent and the current account deficit may exceed $£ 12$ billion.

The analysts could justifiably jeer if their forecasts for these three key variables had been higher. In fact, the City consensus in March was that growth would be 2.7 per cent, inflation 3.8 per cent and the current account deficit $£ 4.1$ billion. So, on growth and inflation, the City was lower (and therefore more wrong) than the Treasury, while on the balance of payments the City and the Treasury were practically identical. The City scribblers may not be able to resist the temptation to trade insults with a Chancellor who has made a fool of himself, but they have no right to ridicule the Treasury's forecasting ability.

Of course, this indictment of the City's forecasting record would be less compelling if there had been a wide dispersion of views in the nine forecasts collected by the Treasury. At least one or two brave souls might then have come close to forecasting, in broad terms, what was going to happen to the economy. Sadly all the nine forecasts were closely bunched together and were therefore equally inaccurate. (This is not to say that all City forecasts were unsatisfactory. There may have been others, not included in the nine, which were reasonably correct.)

Indeed, the gap between the City consensus and the likely out-turn is far greater than the gap between the nine separate forecasts. A cynic new to the forecasting game, unaware of the great skill and care with which City analysts carry out their work, their undoubted intellectual courage and the enormous salaries which reward their efforts, might conclude that they are much better at copying each other than at predicting the future course of the economy. 
These remarks may seem snide and unnecessary. But there is an important point at issue.

The so-called 'debate' between Mr Lawson and his City critics hides the failure of virtually the entire British economics profession to foresee, at a sufficiently early stage, how strong the 1988 boom would be. Since policy is driven by forecasts, this failure is largely responsible for the difficult problems of financial adjustment Britain now faces. The tendency of forecasters to imitate one another, rather than to say what they really think, can be blamed for a current account payments deficit exceeding 3 per cent of GDP and a worrying rise in inflation.

Of course, there are more charitable explanations for the lack of differentiation between forecasts than economists' propensity, when asked about the future, to transform themselves into computerized sheep. It may be that the Treasury and the various City firms share the same underlying framework of thought so fully that, by genuinely independent processes of reasoning, they arrive at broadly identical and equally wrong forecasts. It may be, in other words, that the problem does not arise because the modellers are copy-cats, but because they have the same inadequate model.

If so, the important task now is to find out what is wrong with the existing shared framework of thought and with the model which incorporates it, and then to propose a superior method of analysing the economy. Silly namecalling, from either the Chancellor or his critics, is not the way forward.

\section{The Lawson Boom: Not Quite as Bad as the Barber Boom}

From an article 'Will the Lawson boom cause as much inflation as the Barber boom?' in Economic Affairs, AprillMay 1989.

The figures for broad money growth were remarkably similar in the Barber and Lawson booms. However, the Lawson boom caused much less inflation. There were a number of reasons for the contrast, which I discused in this article. The conclusion of the article, that 13 per cent base rates 'will cause a recession if they continue for very long', was - I now think - not quite right. In fact, base rates had to reach 15 per cent before the economy's slowdown became incontrovertible.

Over the last three years monetary growth has been extremely fast. The rapid expansion of the money supply reflects a deliberate decision in mid1985 by the Chancellor of the Exchequer, Mr Lawson, to downgrade broad money in economic policy decisions. The result has been a vigorous and well-defined boom in economic activity, which has obvious parallels with a 
previous boom in the early 1970s when $\mathrm{Mr}$ (now Lord) Barber was Chancellor. Will the Lawson boom be followed by an upturn in inflation similar to that after the Barber boom? Is the monetary overhang today as dangerous as it was in the mid-1970s?

Table 7.1 A comparison of monetary growth in the Barber and Lawson booms

Ratio of broad money to gross domestic product

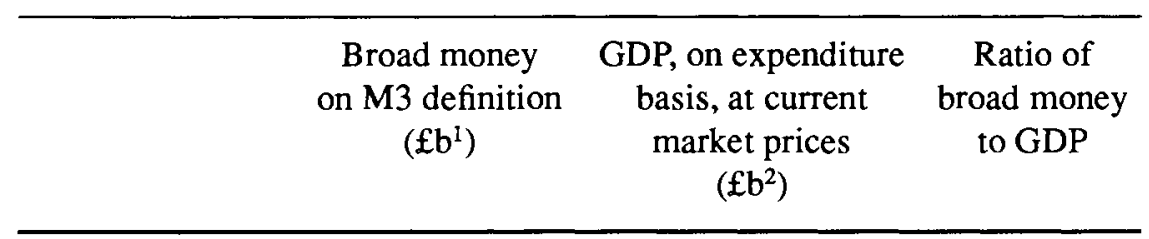

The Barber boom

$\begin{array}{llll}1970 \text { 4th qt. } & 18.2 & 54.1 & 0.336 \\ 1973 \text { 4th qt. } & 33.6 & 76.2 & 0.441\end{array}$

The Lawson boom

$\begin{array}{llll}1985 \text { 2nd qt. } & 118.0 & 351.3 & 0.336 \\ 1988 \text { 2nd qt. } & 201.2 & 448.2 & 0.449\end{array}$

Growth rates of broad money and money GDP

Average annual increase in broad money, on M3 definition (\%)
Average annual increase in money GDP, expenditure basis (\%)

\begin{tabular}{l} 
Three years to \\
4th qt. 1973 \\
Three years to \\
2nd qt. 1988 \\
\hline Notes \\
${ }^{1}$ The figures in 1970 and 1973 have been adjusted upwards by a factor of 1.0976 to make \\
them comparable with those in 1985 and 1988. The upward adjustment reflects a reclassifica- \\
tion in the fourth quarter of 1981 . Other reclassifications have been ignored. \\
${ }^{2}$ At an annualized rate.
\end{tabular}

Source: Economic Trends, various issues 
Some key facts are set out in Table 7.1. There are uncanny resemblances between the two periods. The rise in the ratio of broad money, on the M3 definition, to gross domestic product was almost the same in the three years to end-1973 as it was in the three years to mid-1988, while the ratio of broad money to GDP was only a touch higher in mid-1988 than at end-1973. The annual growth rates of both broad money and money GDP were rather lower, by about 3 per cent and $3^{1 / 2}$ per cent, respectively, in the second episode than in the first, but the difference in growth rates was small compared to their absolute level. In fact, the impression conveyed by Table 7.1 is that the monetary indiscretions of the Lawson boom have been remarkably similar to those of the Barber boom.

If the two booms really are similar, there is a frightening message for future inflation rates. It is clear in retrospect that at the end of 1973 the economy had grossly excessive liquidity and that this excess liquidity could be eliminated only by a large increase in the price level. In the three years to end-1976 the price level rose by 70 per cent, which - in conjunction with a sharp deceleration in monetary growth - brought the ratio of broad money to GDP down to 0.321 . This was roughly the same as it had been six years earlier before the Barber boom began. If an analogous sequence of events were now to unfold, inflation rates of almost 20 per cent would be needed in 1989,1990 and 1991 to absorb the surplus liquidity in the economy. Is that possible? Could the situation really be as bad as that?

Inspection of monetary data is very important. It is a truism that the behaviour of all economic agents, including individuals, companies and the long-term savings institutions, is profoundly influenced by their financial circumstances. In this context the state of anyone's bank balance is obviously crucial. But the link between money and other economic variables is not mechanical. The monetary acceleration since mid-1985 has already caused an increase in inflation, and it will remain a source of inflationary pressure for several years to come. But judgement and analysis are needed to temper inflation forecasts based on crude extrapolations of recent M3 figures.

There are three uncontroversial points which suggest that recent $M 3$ growth rates will not be as inflationary in the next three years as the $\mathrm{M} 3$ growth rates of the Barber boom were in the mid-1970s. The first is that the underlying growth rate of the economy is somewhat more now than it was then. Although a precise estimate is difficult, it seems plausible that the trend growth in productive potential is now about 3 per cent to $3^{1} / 2$ per cent a year, whereas in the mid-1970s it was about 1 per cent a year. Monetary growth can therefore be 2 per cent to $2 \frac{1}{2}$ per cent a year higher without inflationary consequences.

Secondly, deregulation and innovation in the financial system has made it more attractive to hold money assets. For example, as lending restrictions 
have been removed, competition between banks has intensified and a larger number of banks pay interest on a wider range of deposits. The impact of financial innovation in raising the demand to hold money is difficult to assess exactly, but a reasonable 'guesstimate' is that in the early 1980s it had the effect of raising the desired ratio of money to GDP by about 3 per cent or 4 per cent a year. In the mid-1980s an even higher figure may be sensible, because of a special development in the building society movement. As the supply of short-dated government securities diminished, the building societies switched their liquidity from gilts to bank deposits. In mid-1985 the building societies held $£ 3,507$ million deposits with the monetary sector and $£ 991$ million certificates of deposit (CDs); in mid-1988 their deposits with the monetary sector were $£ 9,914$ million and their CDs $£ 7,582$ million. This change in the societies' portfolio preferences has no obvious implications for spending behaviour, but it has accounted for over 15 per cent of the increase in M3 in the three-year period. When allowance is made for it, the desired ratio of money to GDP may have been rising by about 6 per cent a year during the Lawson boom. Of course, financial innovation was also at work in the Barber boom and the mid-1970s, but it does not seem to have been so powerful.

Finally, people and companies are more willing to hold their wealth in monetary form because of a more favourable macroeconomic environment than ten or 15 years ago. Not only does a higher proportion of bank deposits pay interest, but also real interest rates are higher and inflation expectations lower. However, the importance of this influence depends very much on the level of interest rates prevailing at the time. It is not obvious that there has been any significant structural change here compared with mid-1985. If clearing bank base rates were less than the 13 per cent figure now prevailing, economic agents' preparedness to hold bank deposits would be reduced.

In summary, underlying output growth and financial innovation might in recent years have permitted 9 per cent or 10 per cent a year growth in broad money without inflationary consequences. Broad money growth of 13 per cent or 14 per cent would therefore have been consistent with the actual inflation rate of 4 per cent or 5 per cent. Since the growth rate of broad money was in fact $19^{1} / 2$ per cent, excess money was being injected into the economy at a rate of about 5 per cent a year. This boost to liquidity, and the consequent extremely healthy condition of personal and corporate balance sheets, was one of the driving forces - indeed, arguably the key driving force - behind the Lawson boom.

The monetary impulse to higher spending was most potent in the first half of 1988 , because the cut in interest rates encouraged people to move out of interest-bearing financial assets (such as bank deposits) into real assets (such as houses and consumer durables). It was logical that the Lawson boom 
should reach its crescendo at about the same time and that the balance of payments should, in the standard cyclical manner, plunge heavily into deficit shortly afterwards. In mid-1988 the ratio of broad money to GDP was probably about 15 per cent to 20 per cent higher than sustainable in the long run. Since then a very large increase in interest rates has neutralized, at least temporarily, the inflationary threat posed by the excess liquidity.

But the situation is precarious. One of the reasons that the Lawson boom has not led to more inflation is that domestic demand has been diverted overseas by a high exchange rate. The balance of payments, rather than the inflation rate, has acted as the main shock absorber for excess expenditure. Heavy capital inflows, particularly through the banking system, are financing a current account deficit of more than 3 per cent of GDP. These inflows, like the willingness of money-holders to keep surplus balances idle, rely on the extremely high level of interest rates now in force.

But clearing bank base rates of 13 per cent will cause a recession if they continue for very long. A safe conclusion is that 10 per cent inflation, which would be a fitting retribution for the monetary excesses of the Lawson boom, can be avoided only by two to three years of beneath-trend output growth. The monetary legacy of the Lawson boom is less traumatic than that of the Barber boom. But who would have thought three years ago, when the present Conservative Government was so proud of its financial record, that it would so soon face problems of cyclical adjustment similar in character to those of the mid-1970s?

\section{On Property Speculation and Business Entrepreneurship}

From an article 'Boxed in by the boom' in The Times of 25 October 1988.

This article is also self-explanatory, but it was undoubtedly influenced by my involvement as an outside investor in a small business being started up by some friends. The success of the business depended less on their basic competence than on their ability to time correctly decisions to borrow and buy property. This was the microeconomic result of Mr Lawson's macroeconomic mismanagement.

Most British companies nowadays are involved in two distinct activities. The first is creating a product or service and selling it to their customers. The second is amateur property speculation.

This may seem a startling remark, but a little reflection shows how important property is to corporate success in modern Britain. A lively market in commercial and industrial property gives all companies the option to own 
their premises instead of renting, while a highly competitive banking system enables them to finance property acquisition by borrowing rather than from the owners' equity. Land and buildings are often worth much more than stock, machinery and goodwill. Decisions about property and its financing can therefore have a greater influence on profitability than decisions about technology and marketing. Managements with a naive focus on their own business can be bamboozled by managements with a greater awareness of property opportunities. A recent illustration is British Aerospace's coup in obtaining large chunks of under-valued land with its purchases of Royal Ordnance and the Rover Group. But there are countless earlier examples. In the 1960s and early 1970 s the City pages were full of stories about easy fortunes made from asset-stripping.

Property matters less to big business than to small, new businesses. Typically, a small company starts up with a loan from a local bank manager secured against either the premises or the businessman's own house. The interest on the loan is usually a high proportion of costs and may sometimes be the largest single expense. In extreme but not uncommon cases the viability of the business depends only marginally on the ability to make and sell something. Far more crucial is the relationship between interest rates and the rate of increase in property prices, including house price inflation.

The argument should not be pressed too far. It is not valid at all times and in all places. If Britain had been better governed over the last 40 years it would not be of much relevance here. The pivotal role of property management in contemporary business success is not inevitable, but the result of inflation, volatile interest rates and erratic financial policies. Inflation is a nuisance because it is accompanied by high nominal interest rates, needed to compensate savers for the fall in the value of money. High interest rates bite into cash flow and can cripple new businesses, which nearly always have an initial period of liquidity strain.

True enough, the interest charges are offset by the increase in the value of any land and buildings which the business owns. Perhaps, in an ideal world, it ought not to be necessary to pay interest in full. Since both the nominal interest rate and the appreciation of property values reflect general inflation, the inflation component in both cancel out and can be ignored. But in the rough and tumble of everyday business life, banks are not so understanding. They still adhere to the primitive belief that customers ought to repay loans, including accumulated interest. Their difficulty, and also the borrowers', is to know how to assess the true cost of a loan. Is it best measured by the excess of interest rates over the increase in the retail price index, or over the increase in property prices generally, or over the increase in the value of the specific loan and buildings which represent collateral? Everyone agrees that 
inflation reduces the real burden of any given level of nominal interest rates. But how much?

These uncertainties help to explain why interest rate volatility is such a curse. Over the last 11 years clearing bank base rates have varied between 5 per cent and 17 per cent. No one knows with any confidence, whether interest rates 12 months from now will be 3 per cent more or less than they are today. Since the rate of property price appreciation is high when interest rates are low, and vice versa, it is critical to the small businessman when he establishes his company. An investor in, say, a restaurant or hotel at a favourable point in the property cycle (for example, 1970 or 1981), is far more likely to make money than someone who instead chose an unlucky moment (1973 or 1979).

Management skill benefits society. If industry makes more high-quality products and markets them successfully, national output increases. By contrast, astuteness in predicting interest rates adds little or nothing to economic welfare. It is, in economists' jargon, a zero-sum game. It may yield positive returns to certain individuals (those who invested in 1970 or 1981), but these must be offset by negative returns to others (those who invested in 1973 or 1979). Because of macroeconomic turbulence, a fixation with the property market and interest rate gyrations has become part of the British way of life. A return to price stability and an associated move in interest rates to lower and more settled levels are needed if genuine entrepreneurship is to replace small-time property speculation.

It is here that we see the connection between three well-known Thatcherite themes: the case for a sound currency, the virtues of effort and thrift, and the enthusiasm for small business. It is here also that we see just how damaging that Lawson boom has been to the Conservatives' long-term economic programme. The wild increase in London office prices in 1986 and 1987, the 40 per cent surge in house prices nationally over the last 18 months and the recent $4 \frac{1}{2}$ per cent jump in interest rates will all reinforce the widely-held belief that correct timing in the property market is essential to business success. The eradication of the boom-bust mentality was central to the present Government's original agenda. But the excesses of the last three years have obliged businessmen once again to worry more about the stop-go cycle and less about the really important tasks of managing, producing and selling. 